\title{
How to Investigate Four-way Nutrient Interactions in Plants: A New Look at Response Surface Methods
}

\author{
Ellen T. Paparozzi ${ }^{1}$, Walter W. Stroup ${ }^{2}$, and M. Elizabeth Conley ${ }^{1}$ \\ Department of Agronomy and Horticulture and Department of Statistics, University of Nebraska, \\ Lincoln, NE 68583
}

\begin{abstract}
AdDitional INDEX WORDS. nitrogen, sulfur, iron, manganese, deficiency, yellowing, chlorosis, poinsettia, response surface design, Hoerl model

Abstract. Response surface methods refer to a set of experimental design and analysis methods to study the effect of quantitative treatments on a response of interest. In theory, these methods have a broad range of applicability. While they have gained widespread acceptance and application in manufacturing and quality improvement research, they have never caught on in the agricultural sciences. We propose that this is because there has not been specific research demonstrating their usage. In this paper, two $3^{4}$ factorial experiments were performed using 100 poinsettia plants (Euphorbia pulcherrima Willd. ex Klotzsch) to measure nutrient element concentrations in leaves at three rates each of nitrogen (N), sulfur (S), iron (Fe), and manganese (Mn). Three different methods of analysis were compared-the standard analysis of variance with no regression model, the quadratic regression model commonly assumed for most standard response surface methods and the Hoerl model regression, a nonlinear alternative to quadratic response. Actual nutrient element values were compared with the values predicted by each regression model and then also evaluated to see if the visual symptomology of yellowing related to those nutrient concentrations in leaves. The Hoerl model demonstrated better ability to detect biologically relevant nonlinear two-, three-, and four-way nutrient interactions. Though there was minimal replication this model characterized the treatment effects while keeping the size of the experiment manageable both in terms of time (labor) and cost of plant analyses. Additionally, it was shown that when $\mathrm{S}, \mathrm{Fe}$, and/or Mn were deficient along with $\mathrm{N}$, their visual deficiency symptoms were masked by the overall yellowing associated with $\mathbf{N}$ deficiency. This model is recommended as the initial experiment in a series where scientists are looking to expand information already determined for two factors. Other treatment systems that this can be used with include: levels of irrigation, pesticides, and plant growth regulators.
\end{abstract}

Research in the area of plant nutrition is time consuming and expensive. Yet it is important work and still in demand by commercial growers. However, universities, a major source of research in plant nutrition, now expect faculty to acquire large grants and then use that as a measure of the scientist's success. Unfortunately, large grants for basic or applied research on the nutrition of horticultural crops are limited and universities, generally, are faced with static or declining budgets. So, the question we asked is how can plant nutrition researchers still attack research problems with limited funds? The answer is by planning and working smarter, not harder, by focusing on a limited number of treatments rather than all possible combinations. A knowledgeable use of statistics can allow us to do this.

Historically, plant nutrient research has been a stimulus for innovation in the design and analysis of experiments. Mitscherlich (1909) derived nonlinear functions relating plant response to fertilizer N. Gompertz (1825) developed nonlinear functions that were adapted in the early 1900s for use in plant nutrition research. Myers (1990) describes applications of the Gompertz and Mitscherlich models. R.A. Fisher introduced analysis of

Received for publication 28 June 2004. Accepted for publication 12 Oct. 2004. Plant material was donated by Ecke's Poinsettias Inc. This article is submitted as Nebraska Agricultural Research Division journal series no. 14645. This research was supported in part by funds provided through the Hatch Act and in part by an Agricultural Research Division Interdisciplinary Grant. The authors thank Dr. Erin Blankenship, Statistics Dept., and Dr. Roch Gaussoin, Agronomy and Horticulture Dept., for critically reading the manuscript.

'Dept. of Agronomy and Horticulture. For reprint requests, email address: etp1@unl.edu

${ }^{2}$ Dept. of Statistics. variance to the scientific world via an experiment to assess the effect of manure levels on different potato cultivars (Fisher and Mackenzie, 1923). Plackett and Burman (1946) wrote a seminal paper on optimal designs for multifactor experiments. Box and Wilson (1951) developed the central composite design. Box (1954) continued developmental work and Box and Lucas (1959) wrote what is still the standard paper on design of experiments for nonlinear response functions.

Beginning with World War II, manufacturing and quality improvement concerns began to provide much of the impetus for design and analysis innovation, with emphasis on obtaining information about complex input-response relationships as efficiently as possible. Box and Hunter (1957) established general principles for response surface design construction. The next two decades saw a proliferation of developments in response surface methodology. The major developments include the following. Box and Behnken (1960) developed a well-known class of response surface designs. Box and Hunter (1961a, 1961b) developed fractional factorials. Draper (1960, rotatable designs) and Lucas (1974, composite designs) also made major contributions. With so many design options proposed, papers such as Littell and Mott (1974), Lucas (1976), and Hunter (1985) helped guide researchers in selecting an appropriate design. The Littell and Mott paper is less known, but noteworthy because it discussed computer-aided design selection for agronomic experiments at a time when response surface methods had virtually disappeared from the plant sciences. Myers et al. (1989) wrote an excellent survey of the development of response surface methodology over the 1960s through 1980s. Texts such as Cornell and Khuri (1996) and Myers and Montgomery (2002) provided comprehensive treatment of response surface design and analysis. 
The basic idea of response surface methodology can best be understood in two parts, one involving analysis, the other involving design. The goal in response surface analysis is to characterize a response as a function of several quantitative inputs or treatments. While these quantitative inputs represent a factorial arrangement of treatments, response surface designs do not use all treatment combinations. The goal of response surface design is to estimate this function using as few observations as possible. Therefore, only those treatment combinations required to characterize the treatment-response relationship are observed and, of those, only certain treatment combinations, strategically selected to obtain adequate precision, are replicated. Although manufacturing problems use, for example, tensile strength of a metal as the response and temperature, heating time, and alloy composition as treatment factors, the mathematical principles of the problem are identical to characterizing plant response as a function of various nutrient inputs. Mead and Pike (1975) wrote a review article on response surface applications in the biological sciences, including the plant sciences. They observed that agricultural researchers had generally been slow to adopt, or in many disciplines had not adopted at all, response surface methods despite the fact that they appear to be ideally suited for a wide variety of agricultural research problems, including plant nutrition. With few exceptions, this is still the case today. However, the needs of research, the capacity of modern computers, and perhaps most importantly, new budget realities, have combined to compel plant scientists to take a fresh look at these methods.

Perhaps the most important factors limiting the use of response surface methods for plant nutrition research are: 1) the most common methods assume treatment-response relationships that are inadequate to characterize typical plant nutrient-response systems, and 2) the methods assume that researchers can conduct a series of several small experiments over a period of days or weeks to model more complex systems. Specifically, standard response surface methods assume that responses can be modeled by second order polynomial regression (described in detail in Materials and Methods). Landes et al. (2000) using data from Macz(1997) demonstrated that nonlinear models provided descriptions of commonly occurring response-treatment relationships that were superior to second-order polynomial models. Olson et al. (2001) compared various approaches that suggested possible adaptations of response surface methods suitable for plant nutrition research.

In the late $20^{\text {th }}$ century, applied research in areas such as plant nutrition has received reduced funding, but scientist interest remains strong (Paparozzi, 2003). In the future, as formula funding for land grant universities continues to be converted to competitive grants and costs for plant and soil analyses continue to rise, plant nutritionists will need to become more entrepreneurial in conducting and managing experiments. In this paper, we present our research focusing on reducing costs for plant nutrition experiments by utilizing a minimally replicated response surface design with a novel method of analysis. This design and analysis allows plant nutritionists to survey multiple factors (like different nutrient elements) at multiple levels (rates of application) in order to determine which interactions would merit smaller, fully replicated experiments.

Thus, the objectives of this research were to:

1) devise an improved statistical tool to look at the maximum number of factors with the minimum number of experimental units. In these experiments we look at four factors $(\mathrm{N}, \mathrm{S}, \mathrm{Fe}$, Mn) simultaneously, each at three levels, using 100 plants. In this research, we use an experiment with four factors $(\mathrm{N}, \mathrm{S}, \mathrm{Fe}$, $\mathrm{Mn})$ to explore ways to achieve this objective.

2) use this tool to understand what is happening in plants when multiple factors are changing.

3) demonstrate the usefulness of this tool and show how plant scientists can use it to improve the accuracy and efficiency of their research.

\section{Materials and Methods}

Recalling that response surface methods involve an analysis and a design component, our objectives required conducting a multi-factor experiment (in this case, a $3^{4}$ factorial). The data were then used to identify factorial effects that would need to be estimated by a response surface model. Then we compared models for their suitability. Figure 1 illustrates the main idea. Figure 1A plots data for a representative response variable as a function of the amount of $\mathrm{N}$ and $\mathrm{S}$ applied for a given $\mathrm{Fe} \times \mathrm{Mn}$ combination. Note that a full plot of the data would require nine such plots, one for each $\mathrm{Fe} \times \mathrm{Mn}$ combination - only one is shown here. Figure 1B plots predicted values from a response surface model involving $\mathrm{N}, \mathrm{S}, \mathrm{Fe}$, and $\mathrm{Mn}$ levels (in this case the Hoerl function described below). If the model that produces Fig. 1B provides a plausible representation of the data in Fig. 1A, then it is a suitable response surface model. Regression functions, including the Hoerl, can be estimated accurately using substantially fewer treatment combinations than would be required in a full factorial. Thus, identifying suitable regression models gives us the tool we are seeking in objective 1 and we can use it to address objectives 2 and 3 . This is the principle underlying the materials and methods of this research.

GREENHOUSE EXPERIMENTS. Unrooted terminal cuttings of Eckespoint 'Freedom Red' poinsettia (Paul Ecke Poinsettias, Encinitas, Calif.) were dipped into Hormodin 1 rooting powder (Merck \& Co., Rahway, N.J.), stuck in Oasis wedge strips (Smithers-Oasis, Kent, Ohio), and rooted under intermittent mist. Once well rooted (by 5 weeks), cuttings were planted in 15 -cm-diameter azalea pots containing 1 peat : 1 perlite : 1 vermiculite (by volume) medium amended with calcium carbonate Grid Lime (Reimers-Kaufman Concrete Products Co., Lincoln, Nebr.) to lower pH to 6.0.

Plants were grown in Lincoln, Nebr., (lat. $41^{\circ} \mathrm{N}$ ) in an acrylic glass-covered greenhouse at $20-30{ }^{\circ} \mathrm{C}$ (max day/night). Shade cloth covered the roof exterior the last six weeks of each experiment. Plants received a 4-h night interruption (22:00 to 2:00) using $100-\mathrm{W}$ incandescent bulbs. Plants were grown for $45 \mathrm{~d}$ and then pinched. Two experiments were run for 8 weeks beyond pinch.

The experiments were conducted between February and May/ June of 1998 and 1999. Treatment design was a $3^{4}$ factorial for a total of 81 treatment combinations. Three levels of four nutrients were applied: 50,125 , or $200 \mathrm{mg} \cdot \mathrm{L}^{-1} \mathrm{~N}$ in combination with 0 , 12.5 , or $25 \mathrm{mg} \cdot \mathrm{L}^{-1} \mathrm{~S} ; 0,1.375$, or $3 \mathrm{mg} \cdot \mathrm{L}^{-1} \mathrm{Fe}$; and $0,0.77$, or $1.5 \mathrm{mg} \cdot \mathrm{L}^{-1} \mathrm{Mn}$ (Conley et al., 2002). The low, intermediate, and high levels of each factor were selected because they represent deficient, mid and sufficient levels, respectively. Seventeen of the treatment combinations (Table 1), crucial for obtaining required precision and representing critical statistical markers, were replicated. The center point ( $125 \mathrm{~N}, 12.5 \mathrm{~S}, 1.375 \mathrm{Fe}, 0.77 \mathrm{Mn})$ was replicated four times, the other 16 twice. Four benches in total were used. For the ease of visual comparison, the center point treatment combination was placed at the center of each bench. The replicates of the 16 treatment combinations were placed at random on Bench 4 only. All other treatment combinations (28 

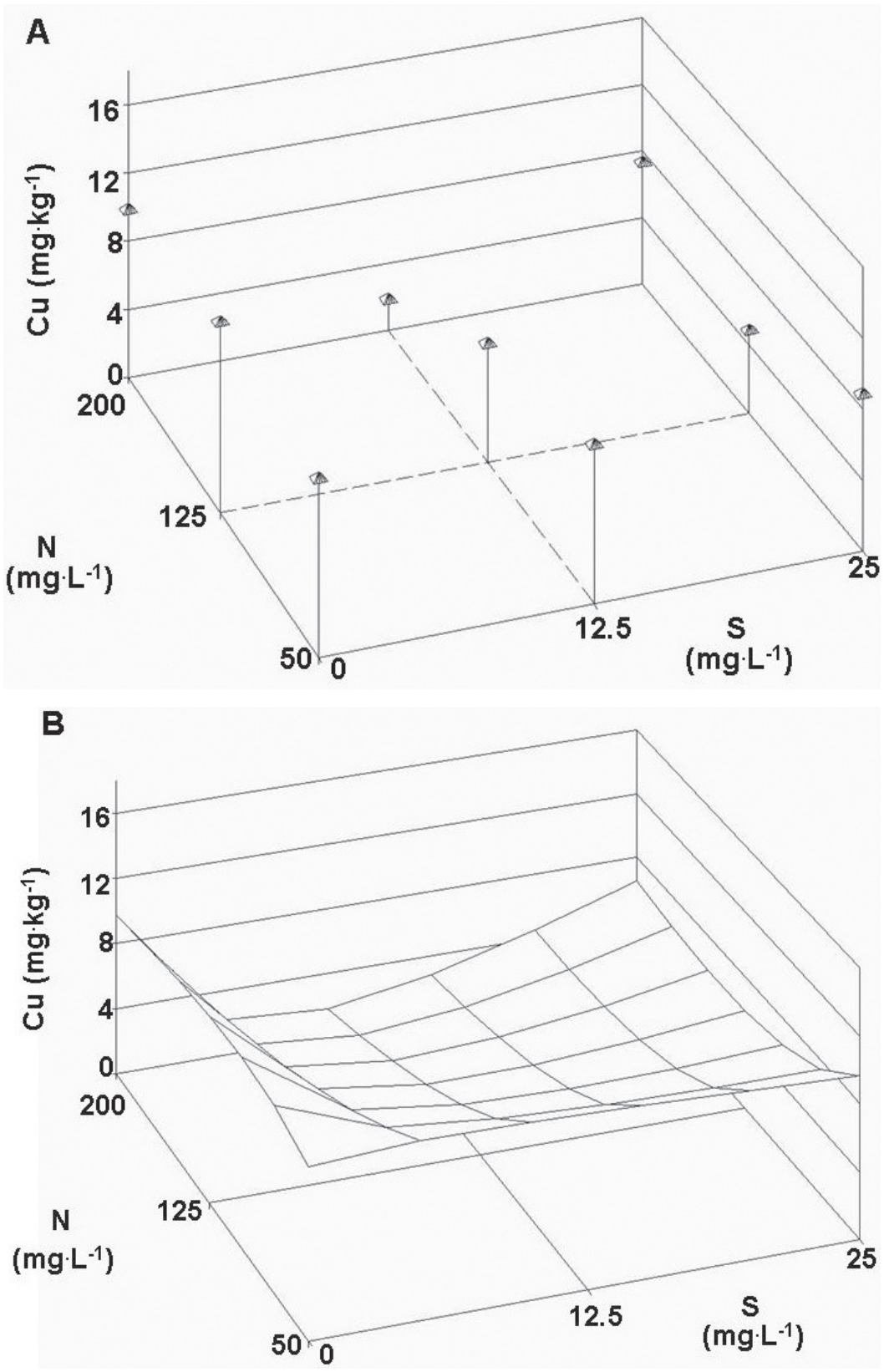

Fig. 1. (A) Two poinsettia experiments were conducted with three levels (deficient, mid level and sufficient) of each of four nutrient factors ( $\mathrm{N}, \mathrm{S}, \mathrm{Fe}, \mathrm{Mn}$ ). This figure shows one example of the observed data (chemically determined $\mathrm{Cu}$ concentration in leaves) from the second experiment. This plot shows observed $\mathrm{Cu}$ concentration for each $\mathrm{N} \times \mathrm{S}$ treatment combination at one $\mathrm{Fe} \times \mathrm{Mn}(\mathrm{Fe}=3, \mathrm{Mn}=0)$ treatment combination. $(\mathbf{B})$ One example of a predicted four-factor response surface generated using the Hoerl Model, which fits the above data. This plot shows observed $\mathrm{Cu}$ concentration for each $\mathrm{N} \times \mathrm{S}$ treatment combination at one $\mathrm{Fe} \times \mathrm{Mn}$ $(\mathrm{Fe}=3, \mathrm{Mn}=0)$ treatment combination. nitrate $\left(\mathrm{NH}_{4}-\mathrm{NO}_{3}\right)$ was $20 \%$ in all treatments. Solutions of micronutrients were prepared from boric acid $\left(\mathrm{H}_{3} \mathrm{BO}_{3}\right)$, sodium molybdate $\left(\mathrm{Na}_{2} \mathrm{MoO}_{4} \cdot 2 \mathrm{H}_{2} \mathrm{O}\right)$, and chelated copper, iron, manganese, and zinc EDTA (Table 3).

For both experiments, nutrients supplied (in $\mathrm{mg} \cdot \mathrm{L}^{-1}$ ) were $72 \mathrm{Ca}, 50 \mathrm{Mg}, 60 \mathrm{P}, 311 \mathrm{~K}, 0-214 \mathrm{Cl}, 0.138 \mathrm{Cu}$, $0.138 \mathrm{Mo}, 0.233 \mathrm{Zn}$, except for B, which was supplied at 0.275 in Expt. 1 and 0.55 in Expt. 2. Supplemental molybdenum $\left(10 \mathrm{mg} \cdot \mathrm{L}^{-1}\right)$ was applied as a drench 15 $\mathrm{d}$ after pinch in Expt. 1. At watering, each pot received $200 \mathrm{~mL}$ solution. Every three nutrient solution applications were alternated with a calcium nitrate solution application. For the 17 treatment combinations that were replicated, when one pot of a treatment needed watering, its replication(s) was also watered.

At harvest, each plant was separated into four samples: newly expanding leaves for $\mathrm{S}$ analysis, the next leaf whorl down for all other nutrients, the stem and remaining leaves, and roots. Leaf samples were air dried and ground to pass a 40-mesh screen using a Wiley mill. All nutrient analyses were done by MDS Harris Laboratories (Lincoln, Nebr.). Total $\mathrm{N}$ was digested using the micro Kjeldahl method, and ammonium was colorimetrically determined using the salicylate-nitroprusside procedure. Chloride was extracted with $2 \%$ acetic acid; $\mathrm{Cl}$ was determined colorimetrically with the mercury (II) thiocyanate method. All other elements were digested according to Huang and Schulte (1985) and analyzed using a Perkin Elmer Optima 4300 ICP (Norwalk, Conn.).

Data were analyzed using three methods, analysis of variance (ANOVA), second-order polynomial regression, and regression using the Hoerl model. These are briefly described as follows. ANOVA was used to compute main effects of N, S, Mn, and Fe, and all possible two-, three-, and four-way interactions. While ANOVAgives an overall summary of the factor effects, it provides no details about the nature of the factor effects and is prone to loss of information, especially about multi-way interactions because of the increasing degrees of freedom associated with these effects (Snedecor and Cochran, 1989). Regression methods address both shortcomings. The regression approach most widely used in response surface methodology is second-order polynomial regression, described in most statistical methods texts. The regression component of the model for this research, i.e., the component that describes effect of factor levels on the response, not including random error, is per bench) were assigned at random to the remaining spaces on the other three benches. There were a total of 100 experimental units (pots) per experiment.

Nutrient solutions for macronutrients were prepared from ammonium nitrate $\left(\mathrm{NH}_{4} \mathrm{NO}_{3}\right)$, magnesium nitrate $\left[\mathrm{Mg}\left(\mathrm{NO}_{3}\right)_{2} \cdot 6 \mathrm{H}_{2} \mathrm{O}\right]$, magnesium chloride $\left(\mathrm{MgCl}_{2} \cdot 6 \mathrm{H}_{2} \mathrm{O}\right)$, potassium nitrate $\left(\mathrm{KNO}_{3}\right)$, potassium phosphate dibasic $\left(\mathrm{K}_{2} \mathrm{HPO}_{4}\right)$, potassium phosphate monobasic $\left(\mathrm{KH}_{2} \mathrm{PO}_{4}\right)$, potassium chloride $(\mathrm{KCl})$, potassium sulfate $\left(\mathrm{K}_{2} \mathrm{SO}_{4}\right)$, and calcium nitrate $\left[\mathrm{Ca}\left(\mathrm{NO}_{3}\right)_{2} \cdot 4 \mathrm{H}_{2} \mathrm{O}\right]$ (Table 2$)$. The $\mathrm{pH}$ of nutrient solutions was adjusted to 6.0 using sodium hydroxide $(\mathrm{NaOH})$ or hydrochloric acid $(\mathrm{HCl})$. The percent of ammonium

$$
\begin{aligned}
y=\beta_{0}+ & \beta_{1} N+\beta_{2} S+\beta_{3} M n+\beta_{4} F e+\beta_{11} N^{2}+\beta_{22} S^{2}+\beta_{33} M n^{2}+\beta_{44} F^{2} \\
& +\beta_{12} N^{*} S+\beta_{13} N^{*} M n+\beta_{14} N^{*} F e+\beta_{23} S^{*} M n+\beta_{24} S^{*} F e+\beta_{34} M n^{*} \mathrm{Fe}
\end{aligned}
$$

where $y$ denotes the response variable.

The second-order polynomial model accounts for linear and quadratic main effects and all two-way interactions involving linear nutrient effects. All other interaction effects are assumed to be negligible. This is essentially a statistical expression of the second-order Taylor-series expansion. Because this expansion does provide a good approximation to many input-response relationships, it is the standard model for response surface methodology. 
Table 1. Two poinsettia experiments were conducted with three levels (deficient, mid-level, and sufficient) of each of four nutrient factors $(\mathrm{N}, \mathrm{S}, \mathrm{Fe}, \mathrm{Mn})$. Of the $3^{4}(81)$ total nutrient combinations, the 17 listed below were replicated. Plant identification (PI) numbers of replicate observations appear in the first column and subsequent columns give levels of each nutrient applied.

\begin{tabular}{lccll}
\hline & \multicolumn{4}{c}{ Nutrient treatment $\left(\mathrm{mg} \mathrm{L}^{-1}\right)$} \\
\cline { 2 - 5 } PI no. & $\mathrm{N}$ & $\mathrm{S}$ & $\mathrm{Fe}$ & $\mathrm{Mn}$ \\
\hline 1,82 & 50 & 0 & 0 & 0 \\
2,83 & 50 & 0 & 0 & 0.77 \\
4,84 & 50 & 0 & 1.375 & 0 \\
5,85 & 50 & 0 & 1.375 & 0.77 \\
9,86 & 50 & 0 & 3 & 1.5 \\
32,87 & 125 & 0 & 1.375 & 0.77 \\
37,88 & 125 & 12.5 & 0 & 0 \\
38,89 & 125 & 12.5 & 0 & 0.77 \\
40,90 & 125 & 12.5 & 1.375 & 0 \\
$41,91,92,93$ & 125 & 12.5 & 1.375 & 0.77 \\
45,94 & 125 & 12.5 & 3 & 1.5 \\
63,95 & 200 & 0 & 3 & 1.5 \\
73,96 & 200 & 25 & 0 & 0 \\
75,97 & 200 & 25 & 0 & 1.5 \\
77,98 & 200 & 25 & 1.375 & 0.77 \\
79,99 & 200 & 25 & 3 & 0 \\
81,100 & 200 & 25 & 3 & 1.5 \\
\hline
\end{tabular}

However, the approximation does not always work well. Landes et al. (2000) discussed the specific shortcomings with respect to plant nutrition. An alternative is the Hoerl model. As described in Daniel and Wood (1980), the Hoerl is a nonlinear model used to predict exponential decay and exponential growth. It has a linearized form, which we used in this research:

$$
\begin{aligned}
y=\beta_{0}+ & \beta_{1} N+\beta_{2} S+\beta_{3} M n+\beta_{4} F e+\beta_{11} \log N+\beta_{22} \log S+\beta_{33} \log M n+\beta_{44} \log F e \\
& +\beta_{12} N^{*} S+\beta_{13} N^{*} M n+\beta_{14} N^{*} F e+\beta_{23} S^{*} M n+\beta_{24} S^{*} F e+\beta_{34} M n^{*} F e \\
& +\beta_{1122} \log N^{*} \log S+\beta_{1133} \log N^{*} \log M n+\beta_{1144} \log N^{*} \log F e \\
& +\beta_{2233} \log S^{*} \log M n+\beta_{2244} \log S^{*} \log F e+\beta_{334} \log M n * \log F e \\
& +\beta_{123} N^{*} S^{*} M n+\beta_{124} N^{*} S^{*} F e+\beta_{134} N^{*} M n^{*} F e+\beta_{234} S^{*} M n^{*} F e \\
& +\beta_{112233} \log N^{*} \log S^{*} \log M n+\beta_{11224} \log N^{*} \log S^{*} \log F e \\
& +\beta_{11334} \log N^{*} \log M n^{*} \log F e+\beta_{22334} \log S^{*} \log M n^{*} \log F e \\
& +\beta_{1234} N^{*} S^{*} M n^{*} F e+\beta_{11123344} \log N^{*} \log S^{*} \log M n * \log F e
\end{aligned}
$$

That is, the model accounts for all linear main effects and interactions, all nonlinear main effects (through the log of the factor level applied) and all interactions composed of the nonlinear (log level) factor effects. This accounts for the fact that nutrient-response
Table 3. Two poinsettia experiments were conducted with three levels (deficient, mid-level, and sufficient) of each of four nutrient factors (N, S, Fe, Mn). Microelement concentrations were as shown below. Treatment solutions which did not contain Fe or Mn had no Fe or Mn added to them, but did contain all other micronutrients.

\begin{tabular}{lccl}
\hline Microelements & $\begin{array}{c}\text { Application rate } \\
\left(\mathrm{mg} \cdot \mathrm{L}^{-1}\right)\end{array}$ & $\begin{array}{c}\text { Concn } \\
(\mathrm{mm})\end{array}$ & \\
\hline $\mathrm{Fe}$ & 1.375 & 24.62 & \\
& 3.00 & 53.72 & \\
$\mathrm{Mn}$ & 0.77 & 14.02 & \\
& 1.50 & 27.30 & \\
$\mathrm{~B}$ & 0.275 & 25.44 & Expt. 1 \\
& 0.55 & 50.88 & Expt. 2 \\
$\mathrm{Cu}$ & 0.138 & 2.17 & \\
$\mathrm{Mo}$ & 0.138 & 1.44 & \\
$\mathrm{Zn}$ & 0.223 & 3.41 & \\
\hline
\end{tabular}

relationships are typically nonlinear, but not smooth enough to be captured accurately by quadratic regression, and interactions are often more complex than two-way, linear-by-linear effects.

Note that the polynomial regression model could also be expanded to account for higher-order interactions analogous to those in the Hoerl model. In the polynomial model, quadratic terms appear in place of the log terms used in the Hoerl model. This was tried and abandoned because the quadratic terms assume a parabola, whereas the log terms assume a response profile more characteristic of dose-response relationships in plant science.

For each regression model, the regression coefficients were estimated, predicted values were computed for each model and compared to the observed responses for each treatment combination. Lack of fit was assessed in three ways. First, residuals (observed minus predicted value) for each treatment combination, and Studentized residuals (residual divided by its standard error) were computed. Residuals were evaluated with particular attention to those discrepancies that would lead to qualitative changes in conclusions, e.g., would the elemental concentration of the plant be falsely diagnosed as critical or toxic. Second, the $R^{2}$ value (percent of variation accounted for by each model) and the adjusted $R^{2}$ (to account for differences in the number of parameters of each model) were determined. Finally, higher-order interactions not included in the respective models were tested

\begin{tabular}{|c|c|c|c|c|c|c|c|c|c|c|c|}
\hline \multicolumn{3}{|c|}{ Treatment } & \multicolumn{5}{|c|}{$\begin{array}{c}\text { Anions } \\
(\mathrm{mm})\end{array}$} & \multicolumn{4}{|c|}{$\begin{array}{c}\text { Cations } \\
(\mathrm{mm})\end{array}$} \\
\hline & $\mathrm{N}$ & $\mathrm{S}$ & $\mathrm{NO}_{3}$ & $\mathrm{SO}_{4}$ & $\mathrm{PO}_{4}$ & $\mathrm{C} 1$ & Total & $\mathrm{K}$ & $\mathrm{Mg}$ & $\mathrm{NH}_{4}$ & Total \\
\hline$\overline{1}$ & 50 & 0.5 & 1.427 & 0 & 1.937 & 5.06 & 8.424 & 6.011 & 2.057 & 0.3555 & 8.4235 \\
\hline 2 & & 12.5 & 1.427 & 0.39 & 1.937 & 4.230 & 7.984 & 5.621 & 2.057 & 0.3555 & 8.0335 \\
\hline 3 & & 25 & 1.427 & 0.78 & 1.937 & 3.50 & 7.644 & 5.232 & 2.057 & 0.3555 & 7.6445 \\
\hline 4 & 125 & 0 & 4.192 & 0 & 1.937 & 2.834 & 8.963 & 6.012 & 2.057 & 0.893 & 8.962 \\
\hline 5 & & 12.5 & 4.192 & 0.39 & 1.937 & 2.054 & 8.573 & 5.622 & 2.057 & 0.893 & 8.572 \\
\hline 6 & & 25 & 4.192 & 0.78 & 1.937 & 1.275 & 8.184 & 5.232 & 2.057 & 0.893 & 8.182 \\
\hline 7 & 200 & 0 & 7.942 & 0 & 1.937 & 1.559 & 11.438 & 7.949 & 2.057 & 1.429 & 11.435 \\
\hline 8 & & 12.5 & 7.942 & 0.39 & 1.937 & 0.78 & 11.049 & 7.559 & 2.057 & 1.429 & 11.045 \\
\hline 9 & & 25 & 7.942 & 0.78 & 1.937 & 0 & 10.659 & 7.169 & 2.057 & 1.429 & 10.655 \\
\hline
\end{tabular}
to see if there were significant effects not accounted for by the terms in the models. For example, the second-order polynomial model contains two-way interaction terms between linear effects. This leaves $3 \mathrm{df}$ per factor pair for two-way interactions more

Table 2. Two poinsettia experiments were conducted with three levels (deficient, mid-level, and sufficient) of each of four nutrient factors $(\mathrm{N}, \mathrm{S}, \mathrm{Fe}, \mathrm{Mn})$. Cation anion balance for all macroelements and $\mathrm{Cl}$ were the same for both experiments and are listed below. Calcium nitrate applications ${ }^{\mathrm{z}}$ occurred separately from other treatment applications.

${ }^{\mathrm{z}} \mathrm{Ca}\left(\mathrm{NO}_{3}\right)_{2} \cdot 4 \mathrm{H}_{2} \mathrm{O}$ concentration was $1.777 \mathrm{~mm} \mathrm{NO}_{3}$ and $1.78 \mathrm{~mm} \mathrm{Ca}$. 
complex than linear $\times$ linear, as well as all three- and four-way interactions. For the second-order model, all such terms were tested. Similarly, effects not modeled by the Hoerl were also tested. SAS [version 9.1 (SAS Institute, 2002)] PROC GLM, MIXED, and REG were used to compute the analyses, GLM to compute $R^{2}$ predicted values and residuals, MIXED for the ANOVA and regression estimates, and REG for adjusted $R^{2}$. Procedures were used for each purpose listed mainly because of the relative convenience of the output.

\section{Results}

The results will be discussed in three parts. First, there will be a comparison of the different methods of analysis. This discussion will focus on the classical quadratic regression response and the Hoerl model regression response because, as expected, ANOVA gives very little information about higher order interactions. The second part will be devoted to looking at the actual nutrient element values of the leaves and the values predicted by each model in comparison to published standards of deficiency, sufficiency and toxicity. The third section will evaluate the relationship of the visual symptomology of yellowing to the actual and predicted nutrient element concentration in the leaves.

COMPARISON OF THE THREE METHODS OF ANALYSIS. Full ANOVA alone gives very little information about higher order interactions. This is consistent with warnings in standard statistics texts (e.g., Snedecor and Cochran, 1989) who caution that interpretation of these tests is likely to be misleading because of a masking effect

Table 4. Two poinsettia experiments were conducted with three levels (deficient, mid-level, and sufficient) of each of four nutrient factors (N, S, Fe, Mn). The following table shows the results data analysis of nutrient element concentrations in leaves using $2^{\text {nd }}$ order regression. The $R^{2}$ indicates the percentage of variation explained by the model. The adjusted $R^{2}$ takes into account the number of parameters in each model. Lack-of-fit (LOF) indicates whether the model detects all interactions of interest. If LOF was significant $(*)$, the source of the LOF, i.e., the interaction(s) this model does not account for, appear in the table below. Except where noted, interactions listed were significant at $P<0.05$.

\begin{tabular}{|c|c|c|c|c|c|c|}
\hline \multirow{3}{*}{$\begin{array}{l}\text { Element } \\
\text { in leaves }\end{array}$} & \multicolumn{3}{|c|}{ Expt. 1} & \multicolumn{3}{|c|}{ Expt. 2} \\
\hline & & Idjusted & & & Idjusted & \\
\hline & $R^{2}$ & $R^{2}$ & LOF & $R^{2}$ & $R^{2}$ & LOF \\
\hline $\mathrm{N}$ & 0.887 & 0.868 & NS & 0.916 & 0.902 & $*$ \\
\hline & & & & & & $\begin{array}{l}\mathrm{N} \times \mathrm{S} \\
\mathrm{N} \times \mathrm{S} \times \mathrm{Mn} \\
\mathrm{Fe} \times \mathrm{Mn} \\
\mathrm{S} \times \mathrm{Fe} \times \mathrm{Mn}\end{array}$ \\
\hline $\mathrm{P}$ & 0.540 & 0.464 & NS & 0.610 & 0.545 & NS \\
\hline K & 0.66 & 0.604 & NS & 0.589 & 0.522 & NS \\
\hline $\mathrm{Ca}$ & 0.51 & 0.425 & NS & 0.792 & 0.758 & $*$ \\
\hline $\mathrm{Mg}$ & 0.24 & 0.115 & $*$ & 0.600 & 0.535 & $\begin{array}{l}\mathrm{Fe} \times \mathrm{Mn} \\
*\end{array}$ \\
\hline & & & $\begin{array}{l}\mathrm{S} \times \mathrm{Fe}(0.0568) \\
\mathrm{Fe} \times \mathrm{Mn} \\
\mathrm{S} \times \mathrm{Fe} \times \mathrm{Mn}(0.0683)\end{array}$ & & & $\begin{array}{l}\mathrm{N} \times \mathrm{S} \times \mathrm{Fe} \\
(0.0560)\end{array}$ \\
\hline S (Bottom) & 0.743 & 0.700 & NS & 0.958 & 0.952 & $*$ \\
\hline S (Top) & 0.42 & 0.325 & NS & 0.937 & 0.927 & $\begin{array}{l}\mathrm{N} \times \mathrm{S} \\
* \\
\mathrm{~N} \times \mathrm{S}\end{array}$ \\
\hline B & 0.700 & 0.650 & $\begin{array}{l}* \\
\mathrm{Fe} \times \mathrm{N}(0.06)\end{array}$ & 0.672 & 0.618 & NS \\
\hline $\mathrm{Cu}$ & 0.632 & 0.572 & NS & 0.350 & 0.243 & $\stackrel{*}{\mathrm{~N}} \times \mathrm{S} \times \mathrm{Fe}$ \\
\hline $\mathrm{Fe}$ & 0.280 & 0.162 & $\begin{array}{l}* \\
\mathrm{~N} \times \mathrm{Fe} \\
\mathrm{S} \times \mathrm{Fe} \\
\mathrm{N} \times \mathrm{S} \times \mathrm{Fe} \\
\mathrm{S} \times \mathrm{Fe} \times \mathrm{Mn}\end{array}$ & 0.465 & 0.377 & $\begin{array}{l}* \\
\mathrm{~N} \times \mathrm{S}(0.0588)\end{array}$ \\
\hline $\mathrm{Mn}$ & 0.404 & 0.306 & NS & 0.831 & 0.803 & NS \\
\hline Mo & 0.838 & 0.811 & $\begin{array}{l}* \\
\mathrm{~N} \times \mathrm{S}\end{array}$ & 0.702 & 0.653 & $\begin{array}{l}* \\
\mathrm{~N} \times \mathrm{S}\end{array}$ \\
\hline $\mathrm{Zn}$ & 0.326 & 0.215 & $*$ & 0.455 & 0.365 & NS \\
\hline $\mathrm{Cl}$ & 0.800 & 0.766 & NS & 0.973 & 0.968 & $\begin{array}{l}* \\
\mathrm{~N} \times \mathrm{S}(0.0571) \\
\mathrm{S} \times \mathrm{Fe} \\
\mathrm{N} \times \mathrm{Mn} \\
\mathrm{N} \times \mathrm{Fe} \times \mathrm{Mn}\end{array}$ \\
\hline $\mathrm{Al}$ & 0.338 & 0.23 & $\stackrel{*}{\mathrm{~N}} \times \mathrm{S} \times \mathrm{Fe}$ & 0.171 & 0.035 & NS \\
\hline $\mathrm{Si}$ & --- & --- & --- & 0.202 & 0.071 & NS \\
\hline
\end{tabular}


Table 5. Two poinsettia experiments were conducted with three levels (deficient, mid-level, and sufficient) of each of four nutrient factors (N, S, Fe, Mn). The following table shows the results data analysis of nutrient element concentrations in leaves using the Hoerl model. The $R^{2}$ indicates the percentage of variation explained by the model. The adjusted $R^{2}$ takes into account the number of parameters in each model. Lack-of-fit (LOF) indicates whether the model detects all interactions of interest. If LOF was significant (*), the source of the LOF, i.e., the interaction(s) this model does not account for, appear in the table below. Except where noted, interactions listed were significant at $P<0.05$.

\begin{tabular}{|c|c|c|c|c|c|c|}
\hline \multirow{3}{*}{$\begin{array}{l}\text { Element } \\
\text { in leaves }\end{array}$} & \multicolumn{3}{|c|}{ Expt. 1} & \multicolumn{3}{|c|}{ Expt. 2} \\
\hline & & Adjusted & & & Adjusted & \\
\hline & $R^{2}$ & $R^{2}$ & LOF & $R^{2}$ & $R^{2}$ & LOF \\
\hline$\overline{\mathrm{N}}$ & 0.898 & 0.853 & NS & 0.949 & 0.926 & $*$ \\
\hline & & & & & & $\begin{array}{l}\mathrm{N} \times \mathrm{S} \\
\mathrm{N} \times \mathrm{S} \times \mathrm{Mn}\end{array}$ \\
\hline $\mathrm{P}$ & 0.610 & 0.438 & NS & 0.711 & 0.585 & NS \\
\hline K & 0.687 & 0.551 & NS & 0.675 & 0.533 & NS \\
\hline $\mathrm{Ca}$ & 0.613 & 0.444 & NS & 0.858 & 0.797 & NS \\
\hline $\mathrm{Mg}$ & 0.408 & 0.151 & $*$ & 0.713 & 0.589 & NS \\
\hline S (Bottom) & 0.773 & 0.674 & $\begin{array}{l}\mathrm{Fe} \times \mathrm{Mn} \\
\mathrm{NS}\end{array}$ & 0.968 & 0.953 & $*$ \\
\hline S (Top) & 0.502 & 0.286 & NS & 0.95 & 0.928 & NS \\
\hline B & 0.763 & 0.660 & $\begin{array}{l}* \\
\mathrm{~N} \times \mathrm{Fe}(0.0711) \\
\mathrm{Fe} \times \mathrm{Mn}(0.0791)\end{array}$ & 0.777 & 0.680 & NS \\
\hline $\mathrm{Cu}$ & 0.688 & 0.552 & NS & 0.541 & 0.340 & NS \\
\hline $\mathrm{Fe}$ & 0.492 & 0.279 & $*$ & 0.610 & 0.438 & NS \\
\hline Mn & 0.491 & 0.269 & $\begin{array}{l}\mathrm{S} \times \mathrm{Fe} \\
* \\
\mathrm{Fe} \times \mathrm{Mn}(0.0754)\end{array}$ & 0.894 & 0.848 & NS \\
\hline Mo & 0.879 & 0.826 & $\begin{array}{l}* \\
\mathrm{~N} \times \mathrm{Mn}(0.0508)\end{array}$ & 0.86 & 0.800 & NS \\
\hline $\mathrm{Zn}$ & 0.452 & 0.214 & N $\mathrm{N} \times \mathrm{S}$ & 0.560 & 0.368 & NS \\
\hline $\mathrm{Cl}$ & 0.832 & 0.758 & NS & 0.982 & 0.974 & $\begin{array}{l}* \\
\mathrm{~N} \times \mathrm{Mn} \\
\mathrm{N} \times \mathrm{S}(0.066)\end{array}$ \\
\hline $\mathrm{Al}$ & 0.540 & 0.340 & NS & 0.343 & 0.058 & NS \\
\hline $\mathrm{Si}$ & --- & --- & --- & 0.335 & 0.047 & NS \\
\hline
\end{tabular}

as the number of numerator degrees of freedom in the $\mathrm{F}$ statistic increases. For example, the Hoerl has $2 \mathrm{df}$ for four-way interaction: linear $\mathrm{N} \times \mathrm{S} \times \mathrm{Fe} \times \mathrm{Mn}$ and $\log (\mathrm{N}) \times \log (\mathrm{S}) \times \log (\mathrm{Fe}) \times$ $\log (\mathrm{Mn})$. The $3^{4}$ factorial has $16 \mathrm{df}$ total for four-way interaction. The remaining $14 \mathrm{df}$ typically represent noise, their sums of squares are correspondingly negligible, and in the F test they average out the potentially informative $2 \mathrm{df}$. For this reason, the full ANOVA is not discussed again in this paper.

When data were analyzed by the classical regression model, only P, K, and Mn had a lack-of-fit that was not significant (Table 4). Thus, the model adequately characterized the effect of the treatments on these three response variables. All other elements showed a significant lack-of-fit. Since the lack-of-fit term contains potentially important interactions among $\mathrm{N}, \mathrm{S}, \mathrm{Fe}$, and $\mathrm{Mn}$ not identifiable by this model, this means that this model failed to detect important interaction effects. Of greatest concern are the instances, such as occurred with N, S (Expt. 2), and Cl, where the model had a high $R^{2}$ (above $80 \%$ ) and showed lack-of-fit, failing to detect key higher-order interactions among $\mathrm{N}, \mathrm{S}, \mathrm{Fe}$, and Mn. Researchers often look for a high $R^{2}$ as an indicator that the model used in the analysis is providing an accurate assessment of treatment effects.

When data were analyzed by the Hoerl model, P, K, Ca, S (top leaves), and $\mathrm{Cu}$ showed no significant lack-of-fit. Thus, the model accounted for the effect of the treatments on these response variables (Table 5). The Hoerl model accounted for more interactions for $\mathrm{N}$ than the classical regression model (ca. $35 \%$ more). Also, in the case of the response variables $\mathrm{Fe}, \mathrm{Mg}$, $\mathrm{Mo}, \mathrm{Cl}$, and $\mathrm{Al}$, the Hoerl model accounted for more interactions than the classical regression model. For Mn, B, S (bottom leaves), $\mathrm{Zn}$, and $\mathrm{Si}$ either model worked. The Hoerl model always had a higher $R^{2}$ than the $2^{\text {nd }}$ order polynomial, as it must because it has more parameters. The adjusted $R^{2}$ was typically also higher for the Hoerl model particularly for Expt. 2, despite the additional parameters, except where the additional interaction modeled by the Hoerl was negligible.

ACTUAL ELEMENT CONCENTRATION VERSUS PREDiCted. Not all statistically significant effects are biologically significant. Thus, when an interaction is deemed statistically significant, one must verify its relevance by identifying a biological explanation. We imposed biological significance on both regression models in two different ways. First, we used different categories of nutrient sufficiency as described in the literature, i.e., deficient/critical, adequate, high/toxic levels (Table 6). This method of statistical comparison of the real measured value (the data) vs. the value predicted by the model allowed us to determine how good each model was at predicting biological significance. In this research any value that did not fall directly in the normal range was 
Table 6. Two poinsettia experiments were conducted with three levels (deficient, mid-level, and sufficient) of each of four nutrient factors $(\mathrm{N}, \mathrm{S}, \mathrm{Fe}, \mathrm{Mn})$. Listed below are the critical, normal, and toxic levels of nutrients (minerals) that were used for assigning biological significance in the two models (from Ecke et al., 1990).

Mineral analysis interpretation key

for poinsettia leaf tissue ${ }^{z}$

\begin{tabular}{lccc}
\hline Element & Critical level & Normal range & Toxic level \\
\hline $\mathrm{N}$ & 35 & $\mathrm{~kg} \mathrm{~g}^{-1}$ & \\
$\mathrm{P}$ & 1.5 & $40-60$ & 73 \\
$\mathrm{~K}$ & 10 & $3-6$ & 9 \\
$\mathrm{Ca}$ & 5 & $15-35$ & 40 \\
$\mathrm{Mg}$ & 2 & $10-175$ & \\
$\mathrm{~S}$ & 0.5 & $3-10$ & \\
$\mathrm{Na}$ & & $1-3$ & 5 \\
$\mathrm{Cl}$ & $0-4$ & 30 \\
\end{tabular}

\begin{tabular}{|c|c|c|c|}
\hline \multicolumn{4}{|c|}{$\mathrm{mg} \cdot \mathrm{kg}^{-1}$} \\
\hline $\mathrm{F}$ & & $0-4$ & 5 \\
\hline $\mathrm{Li}$ & & $0-15$ & 20 \\
\hline $\mathrm{Cu}$ & 1 & $2-10$ & \\
\hline $\mathrm{Zn}$ & 20 & $25-60$ & \\
\hline Mn & 40 & $60-300$ & 650 \\
\hline $\mathrm{Fe}$ & 50 & $100-300$ & \\
\hline B & 15 & $25-75$ & 100 \\
\hline Mo & 0.5 & $1-5$ & \\
\hline
\end{tabular}

${ }^{z}$ Concentrations are based on oven-dry tissue.

identified as either deficient/critical or high/toxic. For example, if a value of $\mathrm{N}$ was analyzed or predicted to be 3.99999, it was determined to be deficient/critical.

The second method was to select a residual criterion. The residual criterion is a subjective value which describes the magnitude of discrepancy between data observed and values predicted from the model the researcher is willing to accept. In this research the residual criterion was selected based on the published values for the analysis of mineral nutrients in poinsettias (see Table 6 taken from Ecke et al., 1990). For example, when the difference between the actual $\mathrm{N}$ concentration in the leaf and the amount predicted by the two models was greater than or equal to $0.20 \%$ or 2000 $\mathrm{mg} \cdot \mathrm{kg}^{-1}$, the treatment was counted as either overestimated or underestimated. This is shown for the classical regression model and the Hoerl model in Table 7. This count was taken regardless of where the number fell in terms of deficient/critical, normal or high/toxic levels. In Table 7, the column labeled "Interpretation Affected" accounts for the number of treatments that were both over/underestimated and fell out of the proper range for biological interpretation and thus, would mean that the value predicted by the model would be interpreted incorrectly by the researcher. For example, if a N predicted value was $3.79 \%$ and the actual analysis value was 4.01 , this would be scored as "Interpretation Affected" as the researcher would identify that the nutrient was in the deficient/critical level rather than the normal level.

Using these very strict criteria, the classical response surface model generated better predicted values for $\mathrm{K}$ and $\mathrm{Cl}$. The Hoerl model generated better predicted values for $\mathrm{S}$ (both top and bottom leaf samples), B, $\mathrm{Cu}, \mathrm{Fe}, \mathrm{Mn}, \mathrm{Mo}$, and $\mathrm{Zn}$. The values predicted by the Hoerl model for $\mathrm{N}, \mathrm{PCa}$, and $\mathrm{Mg}$ were comparable to those generated by the classical response surface model.

THE RELATIONSHIP OF VISUAL SYMPTOMS AND ACTUAL NUTRIENT CONCENTRATION IN LEAVES. Visual symptoms are often the only indicator a scientist or grower has to identify nutrient problems. We were curious to see if leaf yellowing was a good indicator of nutrient deficiency in cases where three or four elements were simultaneously deficient (Fig. 2). We were also curious to see how and if this was related to the significant interactions detected by each model as well as the analytically measured elemental concentrations.

ACtUAL NUTRIENT LEAF CONCENTRATIONS FROM EXPT. 2. Nitrogen leaf concentrations ranged from deficient through normal, as expected. Leaves from treatments containing $50 \mathrm{mg} \cdot \mathrm{L}^{-1} \mathrm{~N}$ and any level of S, Fe, or Mn were deficient in N (Fig. 2). These plants had yellow leaves and a pronounced reddening of the veins. The fertilizer treatment of $125 \mathrm{mg} \cdot \mathrm{L}^{-1} \mathrm{~N}, 0 \mathrm{~S}$, and any level of Fe or Mn also produced $\mathrm{N}$ deficiency in terms of actual leaf concentrations and somewhat in terms of visual symptomology. Interestingly, plants displayed a lighter overall green color when Fe or Mn were deficient, but did not reliably have an interveinal appearance to the chlorosis. Any plant fertilized with $200 \mathrm{mg} \cdot \mathrm{L}^{-1} \mathrm{~N}$ and either 12.5 or $25 \mathrm{mg} \cdot \mathrm{L}^{-1} \mathrm{~S}$ had a normal leaf $\mathrm{N}$ concentration. All other treatments varied between deficient to normal with no easily discernible trend.

Sulfur leaf concentrations also ranged from deficient to normal levels. As expected, any plants receiving $0 \mathrm{~S}$ and any level of $\mathrm{N}$, $\mathrm{Fe}$, or $\mathrm{Mn}$ were deficient in $\mathrm{S}$ and had typical visual $\mathrm{S}$ deficiency symptoms. Plants fertilized with $50 \mathrm{mg} \cdot \mathrm{L}^{-1} \mathrm{~N}$ and either 12.5 or 25 $\mathrm{mg} \cdot \mathrm{L}^{-1} \mathrm{~S}$ regardless of $\mathrm{Fe}$ or $\mathrm{Mn}$ level had $\mathrm{S}$ leaf concentrations in the critical range. These plants appeared yellow and sometimes interveinal chlorosis appeared. Plants fertilized with $200 \mathrm{mg} \cdot \mathrm{L}^{-1} \mathrm{~N}$ and either 12.5 or $25 \mathrm{mg} \cdot \mathrm{L}^{-1} \mathrm{~S}$ regardless of $\mathrm{Fe}$ or Mn had normal leaf S concentrations. Visually, most of these plants were very green. All other treatments varied between critical and normal with no easily discernible trend.

Phosphorous leaf concentrations ranged between normal (21 plants: $4.9-6.0 \mathrm{~g} \cdot \mathrm{kg}^{-1}$ ) and high levels (29 plants: $\left.6.1-8.3 \mathrm{~g} \cdot \mathrm{kg}^{-1}\right)$. $\mathrm{P}$ leaf concentrations appeared to increase as $\mathrm{N}$ application rates increased such that at $50 \mathrm{mg} \cdot \mathrm{L}^{-1} \mathrm{~N}, 21$ of 33 plants had high $\mathrm{P}$ leaf concentrations and at $200 \mathrm{mg} \cdot \mathrm{L}^{-1}$ all 33 plants had high levels of P. Visual symptoms were not noted and while in most cases $\mathrm{P}$ tended to be high when one or more elements were deficient, there was no consistent pattern.

Potassium leaf concentrations were predominantly in the normal range (91 plants). Nine plants had high/toxic leaf K concentrations (35.1-45.9 $\left.\mathrm{g} \cdot \mathrm{kg}^{-1}\right)$.

Calcium concentrations fell between 4.0 and $9.4 \mathrm{~g} \cdot \mathrm{kg}^{-1}$ and thus, in all plants were at deficient/critical levels. However, related visual symptoms were not detected.

Magnesium leaf concentrations were in the normal range for all treatment combinations.

The majority of leaf $\mathrm{Cu}$ and $\mathrm{B}$ concentrations also fell in the normal range (98 plants $\mathrm{B}$; 99 plants $\mathrm{Cu}$ ).

Iron leaf concentrations ranged between critical and normal levels despite the $0 \mathrm{Fe}$ rates. There were no easily discernible trends in the data. Visually, when Fe was deficient and all other elements were at full strength, interveinal chlorosis was slight and only in the very youngest leaves.

Manganese leaf concentrations ranged between deficient and normal levels, as expected. Here again there were no easily discernible trends in the data. Visually, when Mn was deficient and all other elements were at full strength, interveinal chlorosis was slight and only in the very youngest leaves.

Molybdenum leaf concentrations ranged from deficient (eight plants: $0.3-0.9 \mathrm{mg} \cdot \mathrm{kg}^{-1}$ ) to over normal (toxic level unknown). 
Table 7. Two poinsettia experiments were conducted with 3 levels (deficient, mid-level, and sufficient) of each of four nutrient factors (N, S, Fe, Mn). For the elements listed below, leaf concentration data were analyzed using $2^{\text {nd }}$ order polynomial regression (QPR) and the Hoerl model. Predicted concentrations were determined for QPR and Hoerl models and compared with chemically determined (observed) leaf concentrations. The following table shows the number of observations that were under- or overestimated by each model using residuals (predicted-observed) exceeding the criterion given in the last column. The number of discrepancies that would have affected interpretation (e.g., falsely predicting a deficiency when none was observed) are given in the column labeled "Interpretation Affected." The first value is from Expt. 1 and the second value is from Expt. 2. There were 100 treatments total for each experiment.

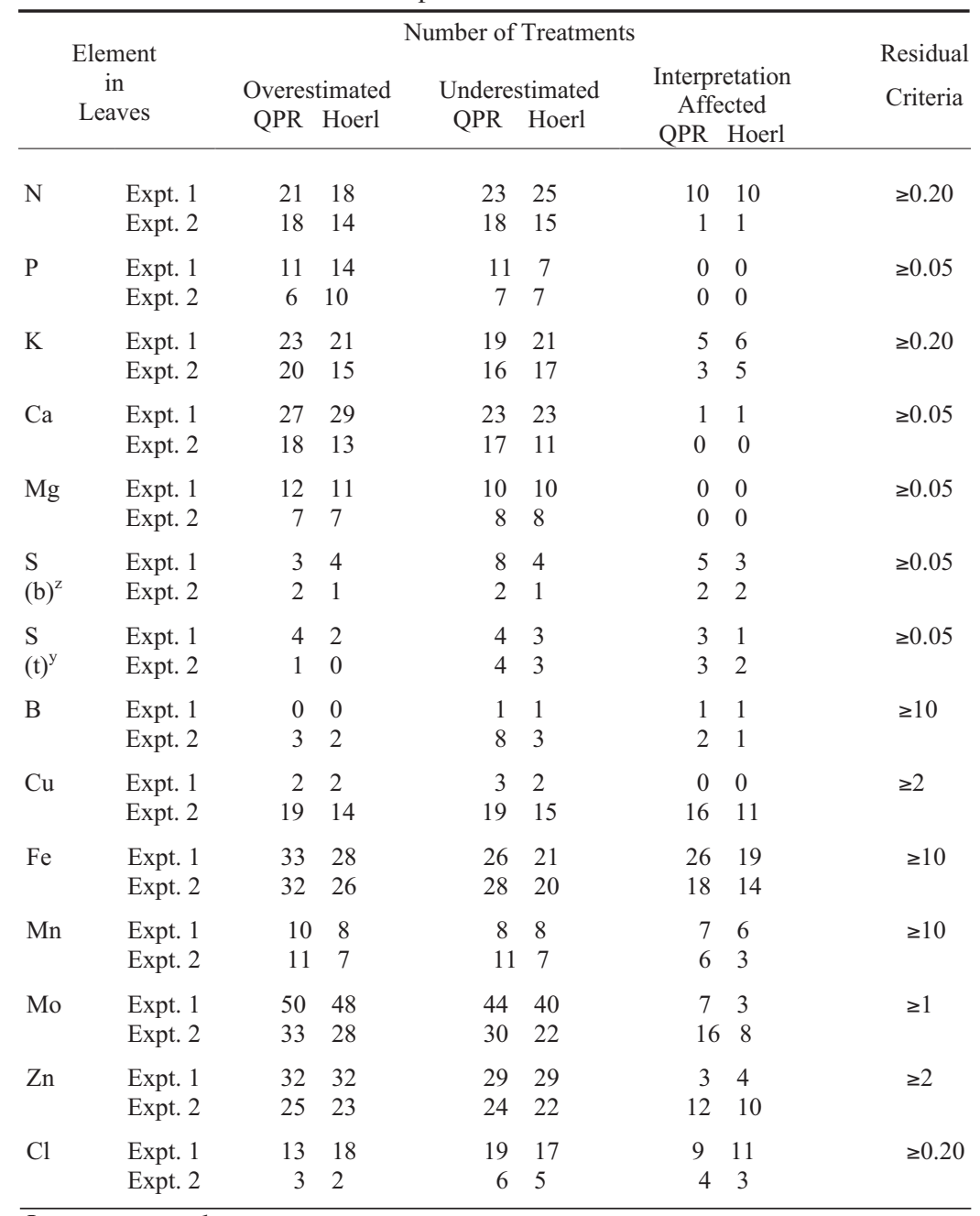

zLower, mature leaves

yTop leaves.

All the deficient plants were receiving only $50 \mathrm{mg} \cdot \mathrm{L}^{-1} \mathrm{~N}$ and either 12.5 or $25 \mathrm{mg} \cdot \mathrm{L}^{-1} \mathrm{~S}$. There was no pattern related to $\mathrm{Fe}$ or Mn application. There occasionally was interveinal chlorosis on the lower leaves (visual symptoms of Mo deficiency), but this occurred in plants that had normal Mo leaf concentrations as well as those with deficient Mo leaf concentrations.

Zinc leaf concentrations fell predominately in the normal range (77 plants) with the other 23 plants showing Zn leaf concentrations in the critical range. Of the latter, deficient/critical concentrations of leaf $\mathrm{Zn}$ tended to be associated with treatments receiving full $\mathrm{Fe}$ ( 22 of 23 plants) and Mn (19 of 23 plants). Visual zinc deficiency was not noted.

Chlorine leaf concentrations ranged from normal (62 plants) through high/toxic (36 plants) levels. This data appeared somewhat to follow $\mathrm{Cl}$ fertilizer concentrations as all 26 treatments receiv- ing low $\mathrm{N}$ and $3.5 \mathrm{~mm}$ or greater of $\mathrm{Cl}$ showed high leaf $\mathrm{Cl}$ concentrations. However, 10 treatments which received $2.8 \mathrm{~mm} \mathrm{Cl}$ or less also showed high $\mathrm{Cl}$ leaf concentrations. All plants receiving $0 \mathrm{~mm} \mathrm{Cl}$ still had between 2.3 and $3.6 \mathrm{~g} \cdot \mathrm{kg}^{-1} \mathrm{Cl}$. No visual symptoms of chlorine toxicity such as burning of leaf tips or margins, bronzing or abscission were recorded.

\section{Discussion}

The Hoerl model demonstrated better ability to detect biologically relevant interactions. As the data from the two experiments in this paper show, complex interactions, both nonlinear two-way and three- and four-way interactions affecting micronutrients do occur among plant nutrient treatments. These interactions were accurately characterized by the Hoerl model, but cannot be detected by the second-order polynomial regression model. As a result, they would be overlooked using classical response surface design and analysis. It is essential that plant nutrition researchers use design and analysis methods capable of measuring the impact of multi-treatment systems as that is how plants are commercially grown.

The Hoerl model in particular lends itself to useful adaptations of response surface designs that keep the required size of the experiment within manageable limits and yield information sufficient to accurately characterize treatment effects. For example, Olson et al. (2001) described a design capable of estimating a four-factor Hoerl model. The design combined a four-factor face-balanced cube with a $2^{4}$ factorial to produce a design with five levels per treatment and 41 treatment combinations observed. Alternative designs can be constructed using either statistical optimal design theory or computer-assisted design (e.g., using SAS PROC OPTEX). Finally, while we have shown that the Hoerl is a useful general purpose model for exploratory plant nutrition research, it is not the only model available. Alternatives such as linear-plateau models and other nonlinear models may be preferable for certain applications. Thus, more research is needed in this area. Regardless of the specific design, the main point is that informative studies on complex plant nutrition systems can be conducted with 100 or fewer plants using the Hoerl model and response surface-derived designs appropriately modified.

As is often the case, the two experiments in this study gave different results. The differences were probably not attributable to seasonal variation as both experiments were run at the same time of year, spring, one year apart. In these experiments, where there is limited replication, discrepancies are of particular concern. The biggest difference between these two experiments may be the experience factor as any time a scientist repeats an experiment with this many treatment combinations, they are bound to do a better job the second time. Thus, the modified Hoerl model-based design and analysis approach described in the previous paragraph should be viewed as part one of a two part process with the first experiment serving as a screening tool to identify critical aspects of the system, factors and specific treatment combinations of interest, that warrant more intensive study. Thus, the second part of the process would be a small experiment with more replication. 


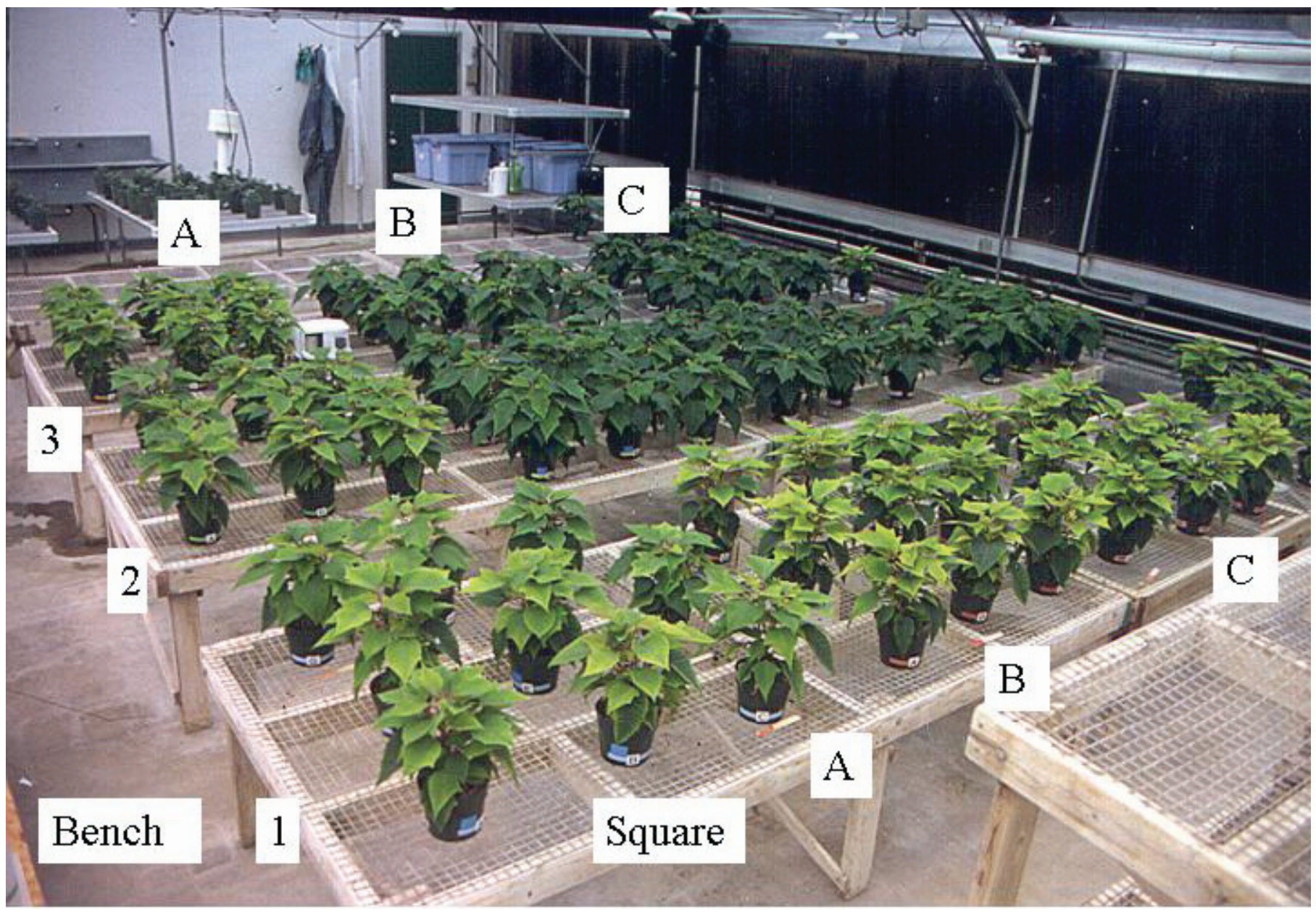

Fig. 2. Two poinsettia experiments were conducted with three levels (deficient, mid-level, and sufficient) of each of four nutrient factors (N, S, Fe, Mn). This figure shows plants at the end of the second experiment. All plants on bench 1 received $50 \mathrm{mg} \cdot \mathrm{L}^{-1} \mathrm{~N}$ with every watering. All plants on bench 2 received $125 \mathrm{mg} \cdot \mathrm{L}^{-1} \mathrm{~N}$ and bench 3 received $200 \mathrm{mg} \cdot \mathrm{L}^{-1} \mathrm{~N}$ with every watering. The nine plants in each square on each bench received $0 \mathrm{mg} \cdot \mathrm{L}^{-1} \mathrm{~S}(\mathrm{square} A), 12.5 \mathrm{mg} \cdot \mathrm{L}^{-1} \mathrm{~S}(\mathrm{square} B)$ and $25 \mathrm{mg} \cdot \mathrm{L}^{-1} \mathrm{~S}$ (square $\mathrm{C}$ ) with every watering. The various iron and manganese treatment combinations plants are within each square. The replications are at the end of each bench. This arrangement of plants was staged to help the reader visualize multi-factor nutrient interactions.

Use of a large, minimally replicated design can save substantial time (labor) and plant analysis costs. For example, a four-factor factorial experiment with three levels per factor requires $3^{4}$ or 81 treatment combinations, whereas the Hoerl-based adapted response surface design allows five levels per factor and requires only 41 treatment combinations. This design can then be replicated and still requires only one more plant that an unreplicated $3^{4}$ factorial. This is an important alternative because it is allows the system to be studied over more levels per factor; it can still estimate all biologically relevant interactions and it is replicated, a situation plant science researchers may find more acceptable. Meanwhile, the most important goal, the quality of information, is substantially improved. For further explanation and an example, visit http://statistics.unl.edu/Tools.

All four of these elements, when deficient, show leaf yellowing symptoms somewhere in the upper portion of the canopy. However, with the two micronutrients, Fe and Mn, the chlorosis is interveinal rather than overall. Whenever $\mathrm{N}$ was deficient regardless of whether $\mathrm{S}, \mathrm{Fe}$, or Mn was also deficient, there was general overall yellowing and that symptomology dominated. This was somewhat true for sulfur, but the trained eye may be able to discern whether $\mathrm{Fe}$ or $\mathrm{Mn}$ were also deficient. When $\mathrm{N}$ was applied at 125 or $200 \mathrm{mg} \cdot \mathrm{L}^{-1}$ in combination with 12 or 25 $\mathrm{mg} \cdot \mathrm{L}^{-1} \mathrm{~S}$ and $\mathrm{Fe}$ and/or $\mathrm{Mn}$ were deficient, interveinal chlorosis on the youngest leaves was slight.

Although the statistical methods discussed here are of obvious value to plant nutrition research, there are many other treatment systems in plants involving varying levels of irrigation; herbicides, fungicides, or insecticides; levels of plant growth regulators in which complex interactions are likely and the methods described here can be used. Tissue culture research with varying levels of salts and plant growth regulators provides another potential application. In general, these methods are applicable in any experiment involving multiple quantitative treatment factors. Specifically these methods should be used first, where biologically relevant interactions among treatments are expected and second, where drawing accurate conclusions or making appropriate recommendations depends on the ability to accurately characterize these interactions.

\section{Literature Cited}

Box, G.E.P. 1954. The exploration and exploitation of response surfaces: some general considerations and examples. Biometrics 10:16-60.

Box, G.E.P. and D.W. Behnken. 1960. Some new three-level designs for the study of quantitative variables. Technometrics 2:455-475. 
Box, G.E.P. and J.S. Hunter. 1957. Multifactor experimental designs for exploring response surfaces. Ann. Math. Stat. 28:195-241.

Box, G.E.P. and J.S. Hunter. 1961a. The $2^{\mathrm{n}-\mathrm{k}}$ fractional factorial designs, part I. Technometrics 3:311-351.

Box, G.E.P. and J.S. Hunter. 1961b. The $2^{\mathrm{n}-\mathrm{k}}$ fractional factorial designs, part II. Technometrics 3:449-458.

Box, G.E.P. and J.M. Lucas. 1959. Design of experiments in nonlinear situations. Biometrika 46:77-90.

Box, G.E.P. and K.B. Wilson. 1951. On the experimental attainment of optimum conditions. J. Roy. Stat. Soc., B 13:1-45.

Conley, M.E., E.T. Paparozzi, and W.W. Stroup. 2002. Leaf anatomical and nutrient concentration responses to nitrogen and sulfur applications in poinsettia. J. Plant Nutr. 25:1773-1791.

Cornell, J.A. and A.I. Khuri. 1996. Response surfaces: Designs and analyses, $2^{\text {nd }}$ ed. Marcel-Dekker, New York.

Daniel, C. and F.S. Wood. 1980. Fitting Equations to Data. Wiley, New York.

Draper, N.R. 1960. Second order rotatable designs in four or more dimensions. Ann. Math. Stat. 31:23-33.

Ecke, P., Jr., O.A. Matkin, and D.E. Hartley. 1990. The Poinsettia Manual. 3rd ed. Paul Ecke Poinsettias, Encinitas, Calif.

Fisher, R.A. and W.A. Mackenzie. 1923. Studies in crop variation. II. The manurial response of different potato varieties. J. Agr. Sci. 8:311-320.

Gompertz, B. 1825. On the nature of the function expressive of the law of human mortality, and on a new mode of determining the value of life contingencies. Phil. Trans. Roy. Soc. A. 115:513-585.

Huang, C.L. and E.E. Schulte. 1985. Digestion of plant tissues for analysis by ICP emission spectroscopy. Commun. Soil Sci. Plant Anal. 16:943-958.

Hunter, J.S. 1985. Statistical design applied to product design. Technometrics 17:210-221.

Landes, R.D., W.W. Stroup, E.T. Paparozzi, and M.E. Conley. 2000. Nonlinear models for multi-factor plant nutrition experiments, $p$. 105-119. In: Proc. $11^{\text {th }}$ Conf. on Appl. Stat. in Agr. Dept. of Statistics.
Kansas State Univ., Manhattan.

Littell, R.C. and G.O. Mott. 1974. Computer assisted design and analysis of response surface experiments in agronomy. Soil Crop Sci. Soc. Florida Proc. 34:94-97.

Lucas, J.M. 1974. Optimum composite designs. Technometrics. 16:561-567.

Lucas, J.M. 1976. Which response surface design is best. Technometrics 18: 411-417.

Macz, O.E. 1997. Nitrogen and sulfur interaction in the production and post-harvest performance of pot chrysanthemums grown in a soilless medium. MS Thesis. Univ. of Nebraska, Lincoln.

Mead, R. and D.J. Pike. 1975. Areview of response surface methodology from a biometric point of view. Biometrics 31:803-851.

Mitscherlich, E.A. 1909. Das gesetz des minimums und das gesetz des abnehmenden bodenertrags. Zeitsscrift furPflanzenernahrung, Dungung und Bodenkunde, 12:273-282.

Myers, R.H. 1990. Classical and Modern Regression with Applications. $2^{\text {nd }}$ edition. PWS-KENT, Boston.

Myers, R.H., A.I. Khuri, and W.H. Carter, Jr. 1989. Response surface methodology: 1966-1988. Technometrics 31:137-157.

Myers, R.C. and D.M. Montgomery. 2002. Response surface methodology: process and product optimization using designed experiments. $2^{\text {nd }}$ ed. Wiley-Interscience, New York.

Olson, L.M., W.W. Stroup, E.T. Paparozzi, and M.E. Conley. 2001. Model building in multi-factor plant nutrition experiments, p. 183-206. In: Proc. 12 ${ }^{\text {th }}$ Conf. on Appl. Stat. in Agr. Dept. of Statistics. Kansas State Univ., Manhattan.

Paparozzi, E.T. 2003. Nutrition of floricultural crops: How far have we come? HortScience 38:1031-1035.

Plackett, R.S. and J.P. Burman. 1946. The design of optimum multifactor experiments. Biometrika 33:305-325.

SAS Institute, 2002. SAS Online Doc 9.1. SAS Inst., Cary, N.C. 29 Sept. 2004. <http://support.sas.com/9.1doc/docMainpage.jsp>.

Snedecor, G.W. and W.G. Cochran. 1989. Statistical methods. $8^{\text {th }}$ ed. Iowa State Univ. Press, Ames. 